\title{
Human-carnivore conflict around Pendjari Biosphere Reserve, northern Benin
}

\author{
Etotépé A. Sogbohossou, Hans H. de Iongh, Brice Sinsin \\ GeERT R. De SNoo and Paul J. Funston
}

\begin{abstract}
Close proximity between humans and large predators results in high levels of conflict. We investigated the extent of, and factors leading to, this conflict through focal group and individual interviews in all villages around Pendjari Biosphere Reserve, northern Benin. Livestock losses from 2000 to $2007(n=752)$ were reported to be mainly caused by spotted hyaena Crocuta crocuta (53.6\%), baboon Papio anubis (24.8\%), and lion Panthera leo (18.0\%). These predators mainly predated sheep and goats $(52.1 \%)$ and pigs $(42.3 \%)$, with lions being the main predators of cattle $(78.9 \%)$. Lion and hyaena diets were more diverse than that of baboons, which killed only small stock. The level of conflict increased during 2000-2007. Predation rate differs between predator species and is significantly influenced by month, rainfall of the month before the predation event, and length of the dry period in a year. The geographical position of the village, the distance of the village to the Park and the number of herbivores legally killed every hunting season also influenced predation intensity. Our findings suggest that improvement of husbandry techniques and education will reduce conflicts and contribute to improved conservation of these threatened predators.
\end{abstract}

Keywords Benin, livestock-predator conflict, Pendjari Biosphere Reserve, predation, predator conservation, West Africa

\section{Introduction}

onsiderable growth of human populations in the last few decades has had a significant negative impact on biodiversity (Hanski, 2005). The degradation of wildlife habitats has resulted in declines of species, many of which are threatened with extinction (Ginsberg \& Macdonald, 1990; Nowell \& Jackson, 1996; Mills \& Hofer, 1998; Woodroffe,

Eтоте́pé A. Sogвоноssou (Corresponding author) Laboratory of Applied Ecology, University of Abomey-Calavi, 03 BP 294 Cotonou, Benin, and Institute for Environmental Sciences, University of Leiden, Leiden, The Netherlands. E-mail etotepe@gmail.com

Hans H. De Iongh and Geert R. DE SNOo Institute for Environmental Sciences, University of Leiden, Leiden, The Netherlands

BRICE Sinsin Laboratory of Applied Ecology, University of Abomey-Calavi, Cotonou, Benin

PAUL J. Funston Department of Nature Conservation, Tshwane University of Technology, Pretoria, South Africa

Received 21 February 2010. Revision requested 22 April 2010.

Accepted 21 May 2010. First published online 12 October 2011.
2000). One of the key factors causing the decline of most large carnivore species is conflict with humans because of predation of livestock (Cozza et al., 1996; Woodroffe, 2000; Treves \& Karanth, 2003) and attacks on humans (Kerbis Peterhans \& Gnoske, 2002; Packer et al., 2005). Humanpredator conflicts cause significant economic losses (Mishra, 1997; Butler, 2000; Patterson et al., 2004; Van Bommel et al., 2007; Palmeira et al., 2008) and can lead to retaliatory killing of predators (Ogada et al., 2003; Holmern et al., 2007), and thus constitute a threat to both wild species and human livelihoods (Woodroffe \& Ginsberg, 1998; Hussain, 2003).

Human-wildlife conflicts have intensified in most African countries in recent decades because of exponential human population growth and economic activities (Woodroffe, 2000; Conover, 2002). The highest intensity conflicts tend to occur where humans live adjacent to protected areas (Mishra, 1997; Conforti \& de Azevedo, 2003). In Africa there are a number of larger predator species, including the lion Panthera leo, leopard Panthera pardus, spotted hyaena Crocuta crocuta, baboons Papio sp., cheetah Acinonyx jubatus, African wild dog Lycaon pictus, caracal Caracal caracal and black-backed jackal Canis mesomelas (Butler, 2000; Patterson et al., 2004; Kolowski \& Holekamp, 2006; Holmern et al., 2007; Van Bommel et al., 2007).

Livestock predation often follows a seasonal pattern (Butler, 2000; Patterson et al., 2004; Kolowski \& Holekamp, 2006) and is influenced by environmental conditions and husbandry practices (Ogada et al., 2003; Kolowski \& Holekamp, 2006). Most studies of predation on livestock in Africa have focused on East and Southern Africa, with few studies from West and Central Africa (Boy, 1962; Sogbohossou, 2004; Bauer \& de Iongh, 2005; Van Bommel et al., 2007; Garba \& Di Silvestre, 2008)

In contrast to East and Southern Africa, West Africa is characterized by low herbivore biomass (East, 1984; Fritz, 1997) and fragmented wildlife populations mostly confined to small, unfenced protected areas that are surrounded by human settlements. The size of many of these reserves doesn't guarantee the long-term conservation of their wildlife species (Woodroffe \& Ginsberg, 1998; Brashares et al., 2001). Thus predation of livestock is inevitable (Binot et al., 2006) and creates a negative attitude to conservation that can lead to the retaliatory killing of carnivores (Kolowski \& Holekamp, 2006; Holmern et al., 2007).

The Pendjari Biosphere Reserve in the Republic of Benin is one of the best managed protected areas in the region, 
with one of the highest wildlife densities in West Africa (Delvingt et al., 1989; Lamarque, 2004). However, the Reserve is located in an important livestock area in one of the poorest parts of the country. Livestock losses thus potentially affect the livelihood of local people. The Reserve is surrounded by a buffer and a hunting zone, intended to minimize human-wildlife conflict. The objectives of this study were to assess: (1) which species are responsible for livestock depredation, (2) any trends and seasonality of predation, (3) patterns of predation, and (4) any other factors that influence the occurrence of predation. We hypothesized that disturbance variables such as presence of safari hunting, poaching and illegal grazing will affect the intensity of livestock depredation.

\section{Study area}

The study was carried out around the Pendjari Biosphere Reserve in north-west Benin (Fig. 1). The Reserve is part of a complex of four adjoining protected areas (W, Pendjari, Arly and Oti-Mandouri) in four adjacent countries (Benin, Burkina Faso, Niger and Togo). Pendjari Biosphere Reserve was established in 1954, upgraded to National Park status in 1961 and to a UNESCO Man and Biosphere Reserve in 1986. It comprises Pendjari National Park $\left(2,660 \mathrm{~km}^{2}\right)$, Pendjari and Konkombri Hunting Zones (c. 1,600 and $251 \mathrm{~km}^{2}$, respectively) and a buffer zone with controlled land-use access for local people (c. $340 \mathrm{~km}^{2}$ ).

The Reserve is bordered to the north and west by the Pendjari River and to the east by the Atacora mountain range. In this Sudanian ecosystem the climate is characterized by a dry season from October to May and a wet season with a total annual rainfall of $800-1,000 \mathrm{~mm}$. Vegetation is a mixture of open grass and tree savannahs interspersed with dry and gallery forests. These habitats harbour a variety of wildlife species including large carnivores (Delvingt et al., 1989). The density of lions in the Reserve is estimated to be between 0.67 (Di Silvestre, 2002) and 1.5 lions per $100 \mathrm{~km}^{2}$ (Sogbohossou, 2009) and the spotted hyaena occurs at a minimum density of 1.5 per $100 \mathrm{~km}^{2}$ (Sogbohossou, 2009). The cheetah and wild dog populations, which almost disappeared, seem to be recovering, although numbers remain low, and there is no estimate of leopard abundance.

The Reserve is bordered by two main roads, TanguiétaPorga and Tanguiéta-Batia, along which there are 24 villages (Fig. 1). In addition to native farmers most villages are also inhabited by Fulani (with one to eight camps in each village), who are pastoralists. During the dry season migrating herds of cattle led by Fulani herdsmen from neighbouring countries reside within or close to the border of the Park in search of water and fodder.

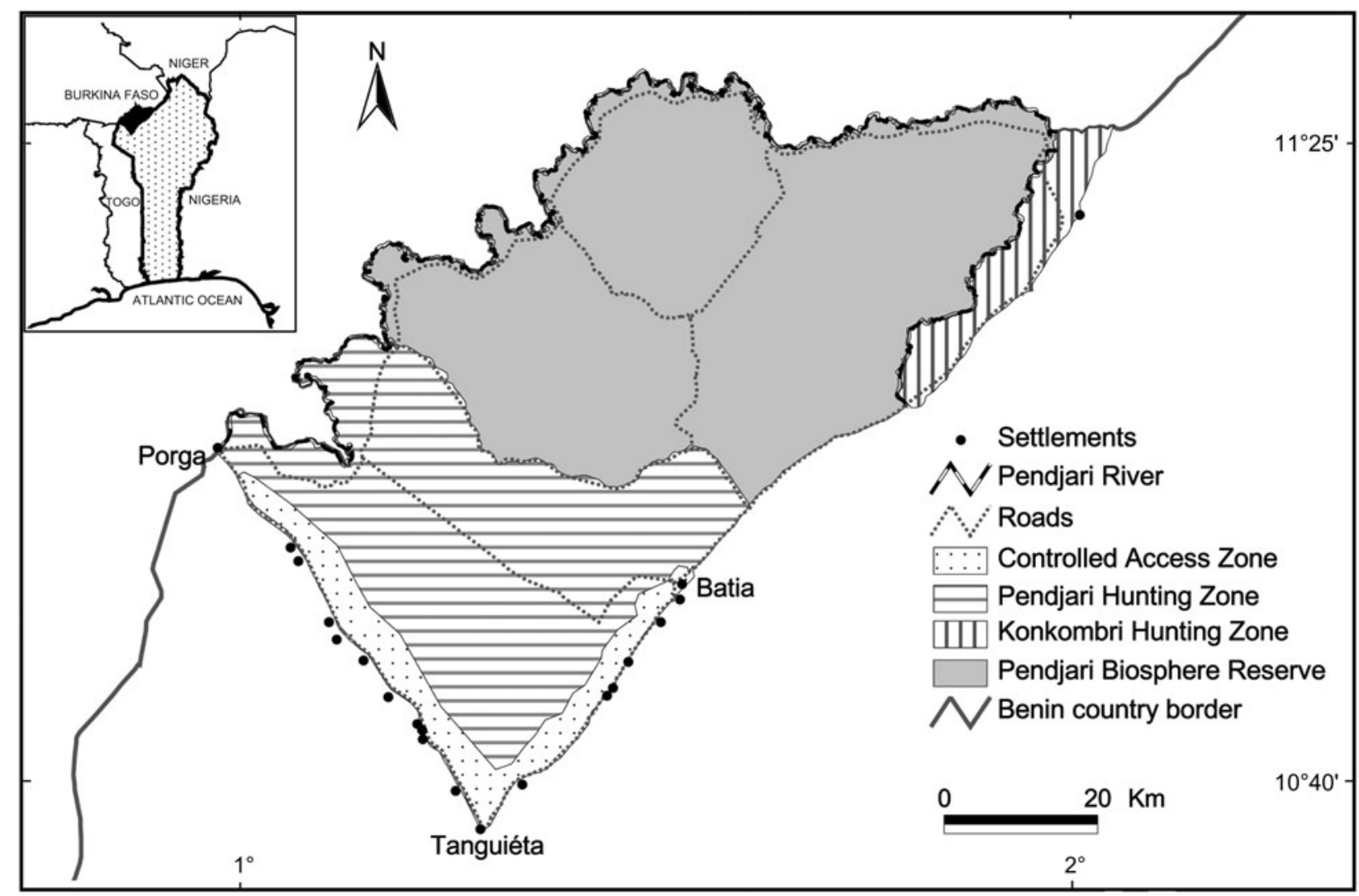

FIG. 1 Pendjari Biosphere Reserve and the surrounding controlled access and hunting zones. The black-shaded area on the inset indicates the position of the Reserve in north-west Benin, West Africa. 
The Reserve has been financed discontinuously through several programmes, with funding gaps almost abandoning the park to poachers during 1982-1985, 1991-1993 and 19982000. Since 2000 the Pendjari Project has managed the Reserve more intensively and illegal activities within the Reserve have largely been curtailed.

\section{Methods}

Data on the characteristics of human-wildlife conflict were collected from June to December 2007. All 24 villages surrounding Pendjari Biosphere Reserve were surveyed. We firstly discussed the history and characteristics of predation in group interviews. We then visited farmers' households and Fulani camps, randomly, to ask more detailed questions about the characteristics of livestock depredation. In each household or camp we interviewed the head and if he was absent his elder son or the head's wife. Other people present in a house usually helped in the recall of depredation cases. A total of 387 farmers' households and 78 Fulani camps participated in the study. All predation cases from 2000 to 2007 were recorded. Group interviews allowed crosschecking of the data. Interviews were conducted by EAS with the help of a local guide. Colour plates of predator species were used during the interviews to ensure correct identification of species and their spoor. Respondents were also asked to describe the characteristics of the species to verify identification.

Data were analysed using SAS v. 9.1 (SAS Institute, Cary, USA). We considered predation by lions, spotted hyaenas and baboons. There were too few records of predation by leopards, cheetahs and wild dogs ( $<3$ per species) for analysis. Other predators (such as jackals, raptors and snakes), which mainly attack poultry, were not considered. The dependent variable is the intensity of depredation expressed as number of livestock killed. The independent variables used are presented in Table 1.

The distance to the closest protected area border (hunting zone or national park) from each village was determined from coordinates obtained with a global positioning system and ArcView v. 3.2 (ESRI, Redlands, USA). $\chi^{2}$ tests were used to compare the intensity of depredation between predator and livestock species. We checked that the variables were not correlated. For variables with a continuous distribution we used a principal component analysis (PCA) to examine which variables significantly influenced the number of predation events (Table 1). We then tested these relationships using the Pearson non-parametric correlation.

For variables without the problem of co-linearity we used general linear modelling (GLM) to assess the relationship between predation intensity/frequency and the independent variables. The dependent variable was normalized using a log transformation. The minimum level of significance considered was $\mathrm{P}<0.05$. The GLM results are provided as $F$ statistics.

\section{Results}

\section{Livestock husbandry}

Agriculture is the main source of rural livelihoods in the villages surveyed, with small-stock (sheep, goats and pigs) husbandry being of secondary importance. Cattle ranching, however, is the principal livelihood of the Fulani herders. Livestock represent savings for both local farmers and Fulani: the sale of small stock provides cash income to compensate for food shortages or to cover other expenses. Other sources of cash income include cotton cultivation, ecotourism and trade of natural resources (wood, straw, fruits) harvested in the Reserve.

Herding characteristics depend on the species and season. At night small stock are usually kept inside compounds or tied to trees. During the rainy season small stock are kept in enclosures, usually made of clay, or tied to trees to prevent them foraging in cultivated fields. In the dry season small stock roam freely in the village.

In the rainy season cattle are left to graze around the villages. During the dry season water and forage close to the villages become scarce and many Fulani herders allow their cattle to graze in the hunting zone. Some $(1.2 \%)$ herders move their cattle to more humid areas in a rainy season migration. In this season $3.8 \%$ of herders leave the vicinity of the protected area to avoid conflicts with farmers caused by the grazing of farms by cattle.

Fulani camps comprise a circle of several huts or tents. Cattle are usually kept inside the circle of huts but sometimes a whole herd or a group of calves is kept in an enclosure made from thorny branches (Acacia spp., Dichrostachys cinerea and Balanites aegyptiaca). Thirteen percent of Fulani herders had received financial support from a project initiated by the Network of West and Central Africa for Lion Conservation to construct claybrick enclosures to keep calves in at night.

\section{Species involved in livestock predation}

Lions (18.0\%), spotted hyaenas (53.6\%) and baboons (24.8\%) were responsible for most livestock mortalities recorded $(n=752)$. Lions and hyaenas mainly attacked livestock during the night, whereas baboon attacks occurred during the day. The mean annual livestock loss per household was 1.8 head. The majority of livestock killed were sheep and goats (shoats, 52.1\%), followed by pigs (42.3\%), with cattle (3.7\%) and dogs (1.9\%) being infrequently taken. Predation intensity varied between predators $\left(\chi^{2}=66.28 ; \mathrm{P}<0.0001\right)$ and between livestock species $\left(\chi^{2}=47.04 ; \mathrm{P}<0.009\right.$; Fig. 2$)$. Cattle were mainly killed by lions, and shoats by baboons and hyaenas. Pigs and dogs were mainly taken by hyaenas and lions. 
TABLE 1 The independent variables considered, by category, that could potentially influence predation occurrence and intensity around Pendjari Biosphere Reserve, and the method of analysis used for each variable.

\begin{tabular}{lll}
\hline Variable categories & Independent variables & Type of analysis* \\
\hline Species involved in predation & Predator species & GLM \\
Trends & Livestock species & GLM \\
Seasonality & Year of predation & GLM \\
& Month of predation & GLM \\
& Season of predation & GLM \\
& Rainfall during month of predation & PCA \& correlation \\
& Rainfall of month before predation & PCA \& correlation \\
& Rainfall of year of predation & PCA \& correlation \\
Geographical distribution & Rainfall of year before predation & PCA \& correlation \\
& Duration of last dry period (months, days) & PCA \& correlation \\
& Road axis & GLM \\
Other factors & Village & GLM \\
& Distance from village to hunting zone & PCA \& correlation \\
& Distance from village to park & PCA \& correlation \\
& Number of herbivores hunted in previous year & PCA \& correlation \\
& Number of lions hunted in previous year & PCA \& correlation \\
& Number of illegal herders arrested in last 2 months & PCA \& correlation \\
& Number of illegal herders arrested in last 6 months & PCA \& correlation \\
& Number of illegal poachers arrested in last 2 months & PCA \& correlation \\
& Number of illegal poachers arrested in last 6 months & PCA \& correlation \\
\hline
\end{tabular}

${ }^{*}$ GLM, general linear modelling; PCA, principal component analysis

\section{Trends and seasonal distribution of predation}

Predation intensity seemingly increased from five cases in 2000 to 222 cases in 2005 (Fig. 3), followed by a decline. Predation intensity varied by month $(F=4.43, \mathrm{df}=11$, $\mathrm{P}<0.0001)$ but not by season $(F=2.40, \mathrm{df}=1, \mathrm{P}=0.12)$. There was a peak at the end of the dry season in June-July and another at the end of the wet season in December (Fig. 4). This peak was particularly noticeable in the villages bordering the Atacora mountain range along the TanguiétaBatia road. On the Tanguiéta-Porga road a less pronounced peak is evident in the middle of the wet season to the beginning of dry season (Fig. 4). Lions and hyaenas mainly

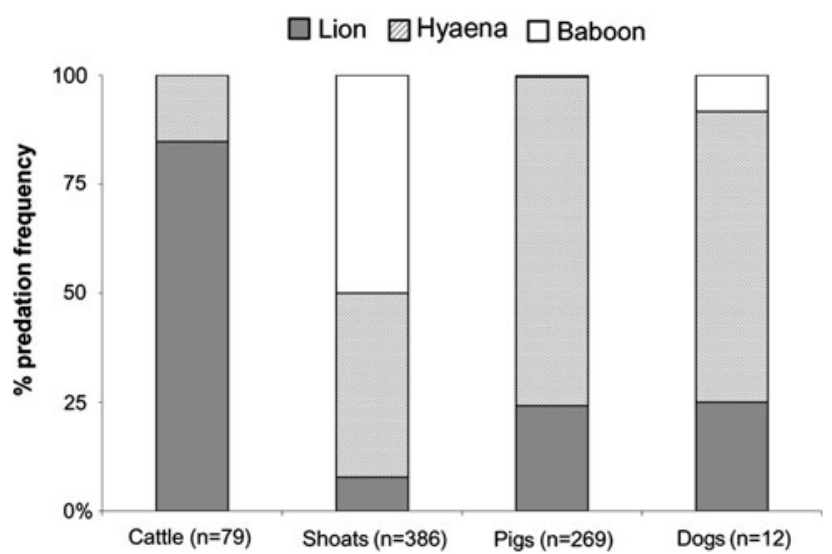

FIG. 2 Overall percentage frequency of attacks by lions Panthera leo, hyaenas Crocuta crocuta and baboons Papio anubis on cattle, shoats (sheep and goats), pigs and domestic dogs from 2000 to 2007 around Pendjari Biosphere Reserve (Fig. 1), based on information from the questionnaire survey. predated livestock from the end of the wet season to the beginning of the dry season, with predation by baboons being most intense at the end of the dry season and from the end of the wet season to the beginning of the dry season.

The intensity of predation decreased when the rainfall of the previous month increased $(r=-0.14, \mathrm{P}=0.007)$. However the rainfall of the current and previous years, and the month of predation, were not significantly correlated with the intensity of predation. The number of dry months in the year was significantly negatively correlated with the intensity of predation $(r=-0.13 ; \mathrm{P}=0.011)$.

\section{Geographical distribution of predation}

The number of predation events was significantly different between the villages around the hunting zone $(F=4.26$, $\mathrm{df}=25, \mathrm{P}<0.001$; Fig. 5). There was a significant difference between the two road axes in the number of livestock killed ( $F=68.18, \mathrm{df}=1, \mathrm{P}<0.0001): 41.3 \%$ of the interviewees along the Tanguiéta-Porga road axis and $14.2 \%$ of interviewees along the Tanguiéta-Batia road axis had lost at least one animal to predation. Livestock predation intensity increased towards the National Park $(r=-0.31 ; \mathrm{P}<0.0001)$ but not relative to the distance from a hunting zone $(\mathrm{P}>0.05)$.

\section{Illegal herding and hunting}

Only the annual number of herbivores killed by safari hunting had a significant impact on predation rate $(r=-0.11$; $\mathrm{P}=0.03)$. The PCA and correlation indicated that the 

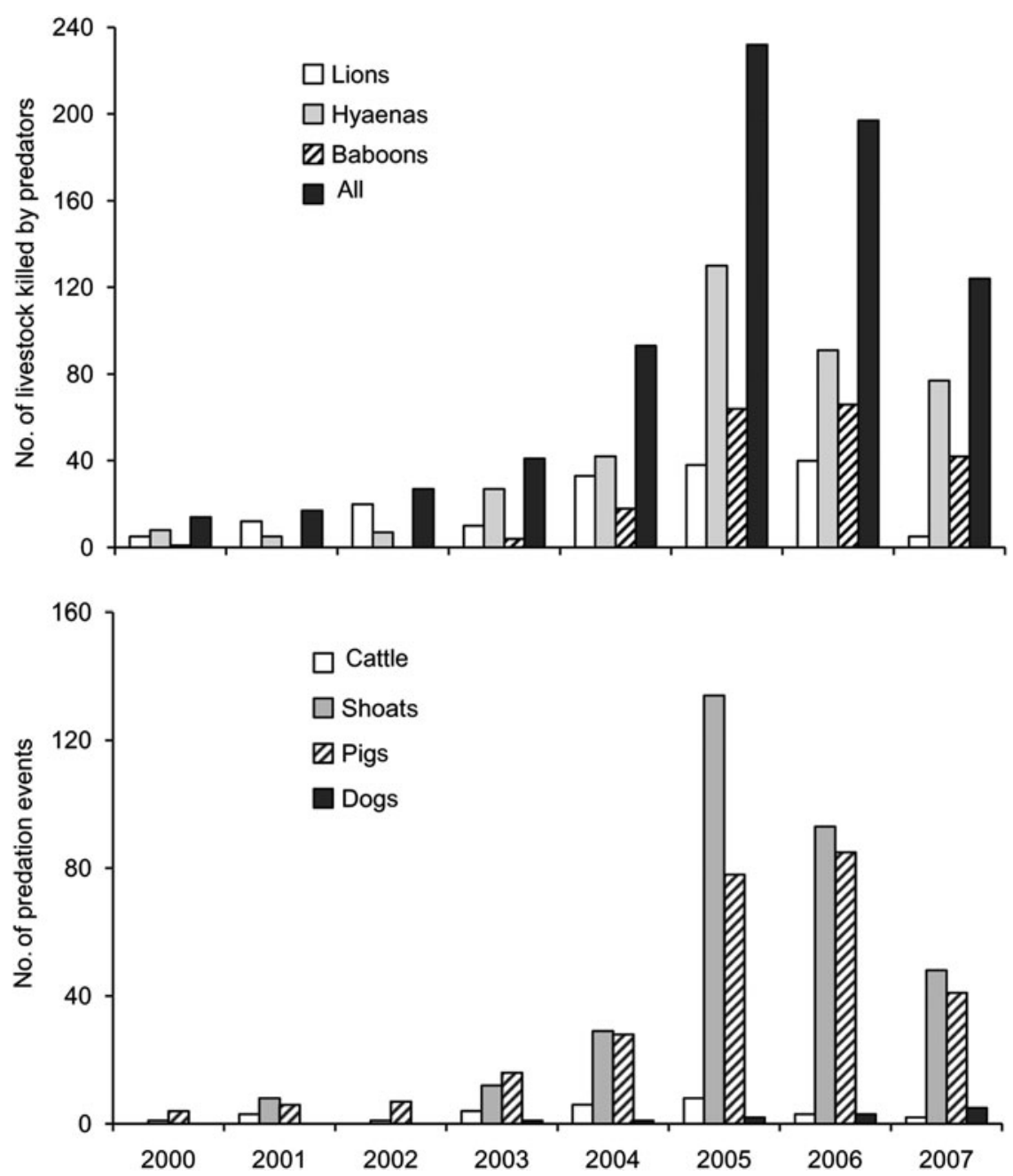

Fig. 3 (a) Total number of attacks by lions, hyaenas and baboons, and the three species combined, on livestock, irrespective of species, and (b) the number of cattle, shoats (sheep and goats), pigs and domestic dogs, killed by all predators combined, around Pendjari Biosphere Reserve (Fig. 1) from 2000 to 2007 , based on the questionnaire survey.

number of poachers and the number of herders arrested in the National Park in a year may have affected the intensity of predation in that year but the impact on predation intensity was not significant $(\mathrm{P}>0.05)$.

\section{Discussion}

A generic problem with using questionnaires to assess depredation is that people invariably attribute livestock mortality to predators (Wagner, 1988; Hoogesteijn et al., 1993; Rasmussen, 1999). We believe that potential bias was minimal in this study as each interviewee generally reported few cases of depredation, and the low numbers involved may have helped the respondents remember specific cases. In many instances we obtained confirmation of predation events from neighbours.

There are several possible explanations for the recorded increase in predation intensity following the more intensive management of the Pendjari Biosphere Reserve that commenced in 2000. Firstly, the implementation of a manage- ment plan may have enhanced predator populations in the Reserve (Oli et al., 1994; Saberwal et al., 1994; Mishra, 1997; Wang \& Macdonald, 2006). Survey data suggest that the number of lions in the Reserve increased between 2002 (Di Silvestre, 2002) and 2009 (Sogbohossou, 2009). Alternatively, depredation could have increased because of growth of the human population, with increased encroachment, reduced natural prey populations and unfavourable habitat changes (Thouless \& Sakwa, 1995; Cozza et al., 1996; Meriggi \& Lovari, 1996; Mladenoff et al., 1997; Dahle et al., 1998; Mizutani, 1999; Woodroffe, 2000; Liu et al., 2001; Naughton-Treves et al., 2003; Treves \& Karanth, 2003; Kolowski \& Holekamp, 2006). We believe it most likely that the increase in the number of lions explains the increases in predation intensity (Di Silvestre, 2002; Sogbohossou, 2009).

\section{Prey selection}

Spotted hyaenas, followed by baboons and then lions, were the predominant predators of livestock. As lions are hunted 

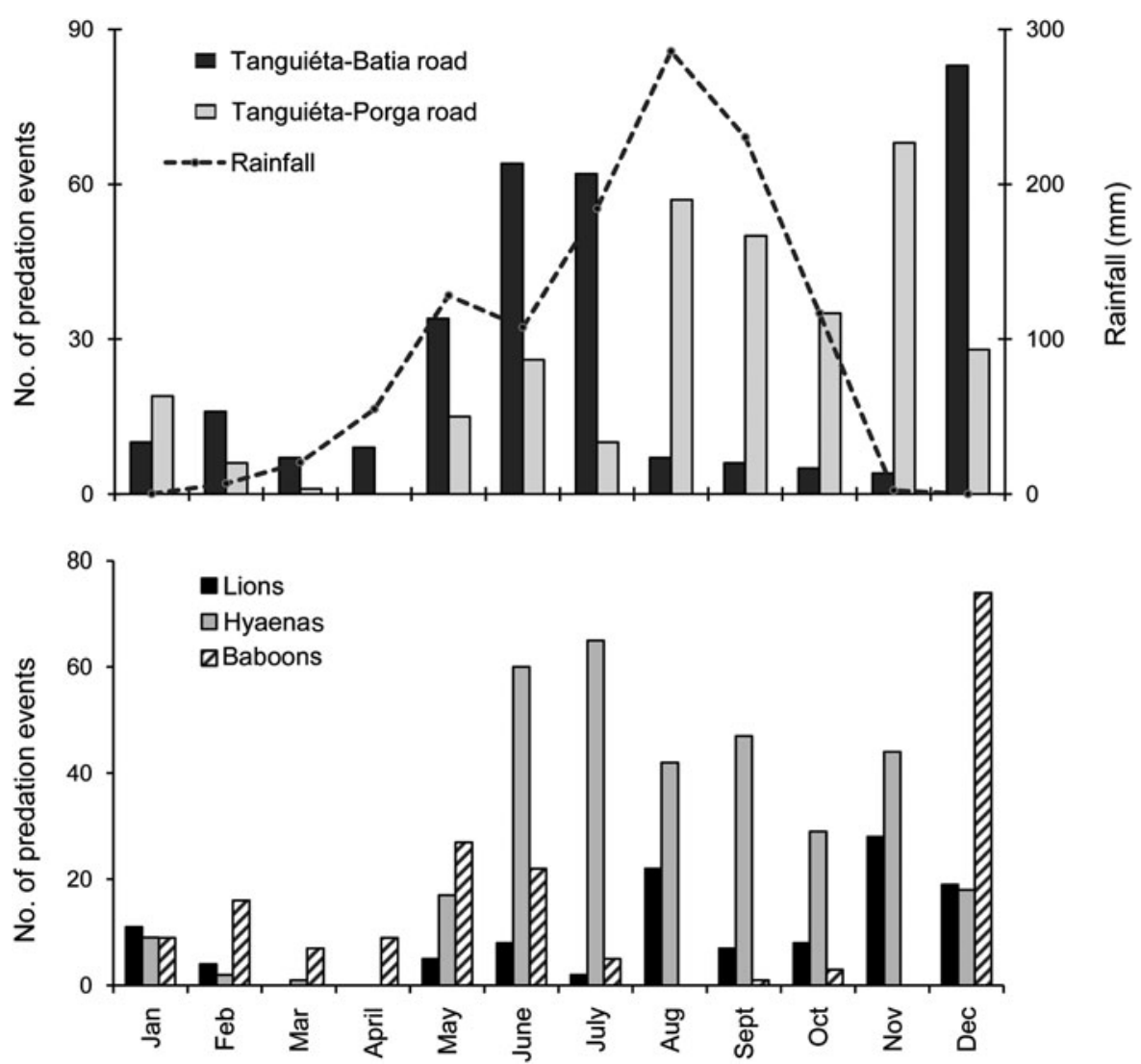

FIG. 4 (a) Total number of monthly predation events along the Tanguiéta-Batia road, which is bordered by the Atacora mountain range, and the Tanguiéta-Porga road, and mean total monthly rainfall, and (b) total number of monthly attacks by lions, hyaenas and baboons, for $2000-2007$.

in the hunting zones it is possible that they occur at lower densities than spotted hyaenas. This, along with the high plasticity of hyaenas, may explain the predominance of hyenas, compared to lions, as livestock raiders (Boydston et al., 2003). In other areas where lions are at high densities they tend to be important livestock predators (Karani, 1994; Kerbis Peterhans \& Gnoske, 2002; Patterson et al., 2004). Similarly, when at high densities spotted hyaenas are responsible for a high proportion of attacks (Holmern et al., 2007). Depredation by baboons, which was relatively important around the Reserve, has rarely been reported to be a significant problem elsewhere (Butler, 2000).

Although lions preyed on small livestock they were principally predators of cattle, whereas hyaenas and baboons mainly attacked small stock. This supports the hypothesis that selection of livestock species corresponds to the size of the predator (Caro, 1994; Patterson et al., 2004) in accordance with the size of their natural prey (Bodendorfer et al., 2006; Hayward, 2006; Bauer et al., 2008). Lions nevertheless killed a higher proportion of small stock in Pendjari compared to Waza National Park area in Cameroon (Van Bommel et al., 2007), Tsavo ranches in Kenya (Patterson et al., 2004) and around the Serengeti National Park in Tanzania (Holmern et al., 2007).

\section{Seasonality of predation}

Livestock predation usually follows seasonal patterns (Oli et al., 1994; Michalski et al., 2006) although there are some exceptions (Holmern et al., 2007). We recorded a peak in predation by lions and hyaenas in the late wet season, similar to what has been observed in Tsavo (Patterson et al., 2004). This is presumably explained by the variation in prey dispersal with season. During the dry season wild herbivores tend to concentrate near water sources within the Reserve, where it is probably easier for lions and hyaenas to prey on them (Kays \& Patterson, 2002). As the wet season progresses and water is more readily available, prey populations disperse widely. In areas with low mean prey density it may be easier for predators to prey upon livestock at these times (Hunter, 1952; Ayeni, 1975; Eltringham et al., 1999). This also probably explains why attacks on livestock were less important in drier years around Pendjari.

However, the pattern of prey movement in relation to the seasonal availability of water may vary from area to area. For example, around Waza National Park lion attacks were only recorded at villages far away from the Park during the wet season, whereas they occurred in all seasons around villages close to the Park (Van Bommel et al., 2007). Thus the season of 


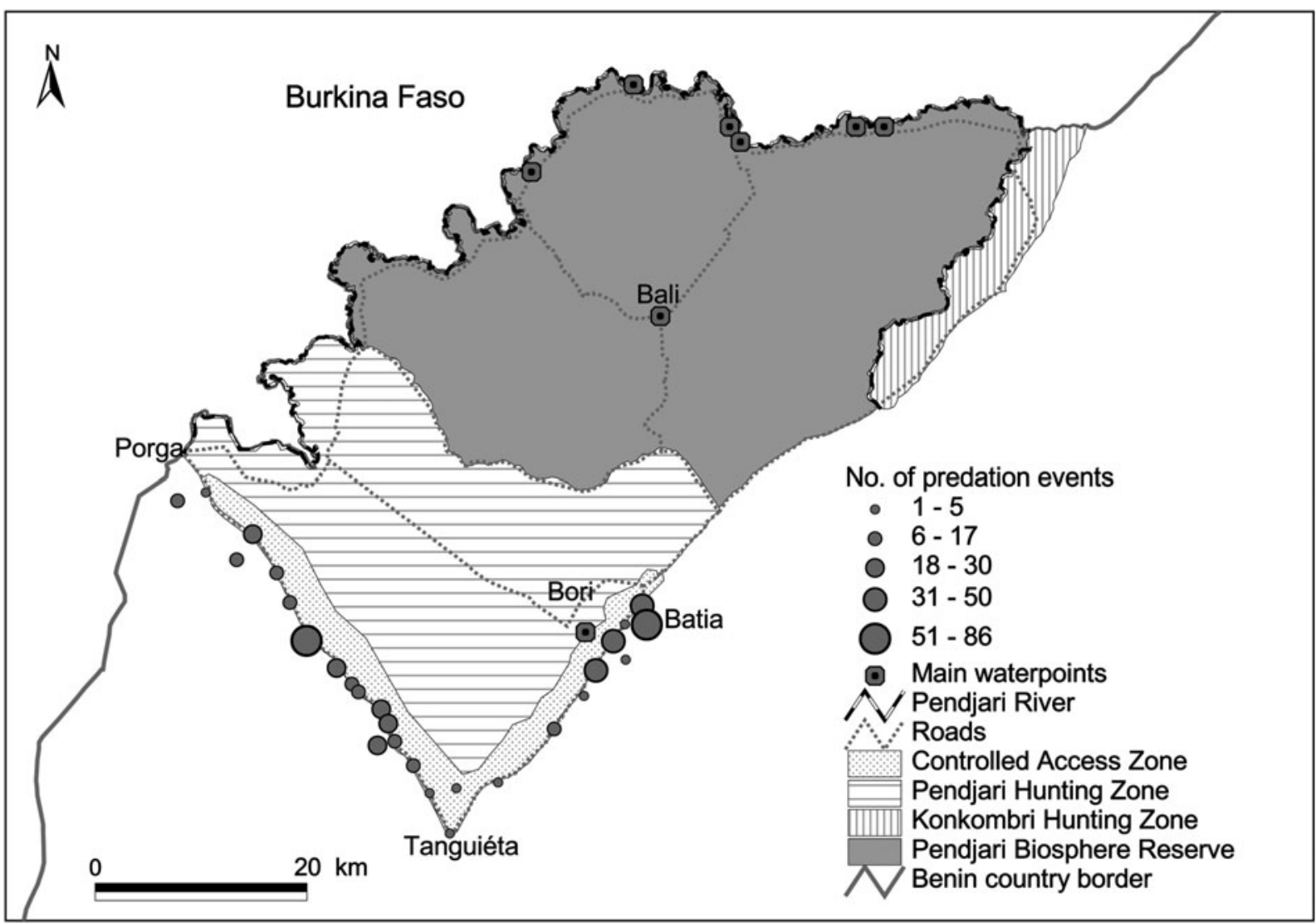

FIG. 5 Predation rates around Pendjari Biosphere Reserve. The size of the circles for each village around the hunting zone indicates the total number of predator attacks during 2000-2007.

peak depredation on livestock is seemingly related to prey distribution and availability and distances of villages from a protected area. In regions where attacks peak in the dry season this may be because, subsequent to migration of prey after the rains, livestock become an easy alternative for resident carnivores (Rudnai, 1979; Karani, 1994). Sometimes predation increases during calving as calves are easier to attack than adult cattle (Polisar et al., 2003; Michalski et al., 2006).

Seasonal predation patterns were different, however, for baboons, which predated livestock mostly during the dry season. This probably explains the difference between the two road axes in the seasonal distribution of predation; baboon attacks are concentrated along the Tanguiéta-Batia road because of its proximity of the Atacora mountains. The dry season begins in November-December, the period when local people set fires to burn the bush. At this time even the hills, a prime baboon habitat, are burned. Thus it probably becomes increasingly difficult for baboons to feed in the wild. Livestock in villages bordering the Atacora mountains thus become an alternate source of food. New forage after the fires draws the baboons away from the villages. Towards the end of the dry season food becomes scarce again, resulting in baboons again predating livestock. Increased predation by baboons in periods of wild food shortage has also been reported in Uganda (Naughton-Treves et al., 1998) and in Zimbabwe (Butler, 2000).

\section{Husbandry techniques}

Husbandry techniques may have a great impact on livestock predation (Robel et al., 1981; Oli et al., 1994; Cozza et al., 1996; Mishra, 1997; Ogada et al., 2003; Patterson et al., 2004; Wang \& Macdonald, 2006; Van Bommel et al., 2007; for a different opinion see Graham et al., 2005).

In the Pendjari area traditional enclosures, which are low, with sparse branches, and the absence of enclosures in most cases, probably encourage livestock predation (Butler, 2000; Mazzolli et al., 2002; Wang \& Macdonald, 2006). Improved fences and walls are inexpensive and are sustainable methods of deterring predators (Jackson \& Wangehuk, 2001; Ogada et al., 2003; Treves \& Karanth, 2003); it would be of value to test them around Pendjari. Dogs are relatively inefficient against predators and also served as prey. Similar cases were reported from around Waza (Van Bommel et al., 2007) and Serengeti National Parks, where hyaenas kill dogs (Holmern et al., 2007). However, guarding dogs and other guarding animals have proved to be successful elsewhere (Marker-Kraus et al., 1996; Bangs \& Shivik, 2001; Marker, 2002; Ogada et al., 2003; Rigg et al., 2011). The efficiency of guarding animals probably depends on the size and character of the breed and on the size of the predator to be deterred. In Pendjari dogs were reported to 
be efficient against jackal and baboon attacks but not against lions or hyaenas.

\section{Other factors}

Our results suggest that distance to the Reserve was strongly correlated with predation risk. This is similar to results from Waza National Park (Van Bommel et al., 2007), the Serengeti (Holmern et al., 2007) and Brazil (Michalski et al., 2006; Palmeira et al., 2008). The effect of distance could be related to species. Lions usually stay close to their natural habitat whereas hyaenas often move far from protected areas (Kruuk, 1972; Hofer \& East, 1993; Mills \& Hofer, 1998; Holmern et al., 2007). In Pendjari it was the distance to the Reserve more than the distance to the hunting zone that influenced predation patterns. Thus the Reserve is the main source of wildlife utilized in the hunting zones, which largely function as a sink and thus as a buffer. This pattern has been found in many other areas (Doak, 1995; Noss et al., 1999). However, the low density of competitors in hunting zones may attract wildlife and predators, which may then further disperse into villages, creating conflicts. Thus it is debatable whether hunting zones successfully act as buffers.

We expected that factors affecting the integrity of the vegetation and of natural prey populations, such as poaching, illegal grazing and safari hunting, would influence conflicts. However, only the number of herbivores shot annually significantly affected the predation rate. The nonsignificant impact of illegal grazing and poaching could be related to the relatively low numbers of herders and poachers arrested every year in the Reserve because of the increase in patrolling by the rangers.

\section{Implications for conservation}

Our findings suggest that conflicts could be significantly reduced by improving husbandry practices. This includes the construction of predator-proof enclosures and a change in herding practices. The park staff, the Wildlife Office and NGOs working in the area should focus on education. As benefits from wildlife can positively affect attitudes (Oli et al., 1994; de Boer \& Baquete, 1998; Conforti \& de Azevedo, 2003; Mishra et al., 2003), decision makers and conservationists need to ensure that people receive benefits from the Biosphere Reserve. Local people are already involved in reserve management, and receive $30 \%$ of the safari hunting revenues. Further studies, however, would facilitate a better assessment of the impact of these revenues and the determinants of people's perceptions and attitudes in this area. Although direct financial compensation is an alternative to the augmentation mitigation measures (Michelle \& Smirnov, 1999; Stahl et al., 2001; Wang \& Macdonald, 2006) this may not be an appropriate approach for a relatively poor country such as Benin where it is already difficult to secure funds for conservation. Any measures applied need to be based on the knowledge of factors that influence local attitudes (Zimmermann et al., 2005) and not just a replication of what is applied elsewhere (Treves \& Karanth, 2003).

Mitigation measures need to be underpinned by a thorough understanding of the socio-ecology and use of space by large predators, which could influence mitigation measures (Stahl et al., 2001). Previous studies, particularly of lions, have shown that conflicts are mostly with problem individuals (Stander, 1990; Woodroffe \& Ginsberg, 1998; Patterson et al., 2004; Bauer \& de Iongh, 2005). To limit the territorial expansion of predators into human settlements around Pendjari Biosphere Reserve investigations are required to identify management actions that need to be conducted in the Biosphere Reserve by the Wildlife Office.

\section{Acknowledgements}

Financial support for this work was provided to EAS by the Netherlands Organization for International Cooperation in Higher Education and Research and a Kaplan Graduate Award from Panthera Foundation. We thank the Wildlife Office (Centre National de Gestion des Réserves de Faune) and the Pendjari Project for allowing us to work in Pendjari Biosphere Reserve. We are grateful to A. Gbangboche, R. Glele Kakai and P. Vos for their help with statistical analyses, and to P. Neuenschwander and two anonymous reviewers for their helpful comments.

\section{References}

A yeni, J.S.O. (1975) Utilization of water holes in Tsavo National Park (East). East African Wildlife Journal, 13, 305-323.

BANGS, E. \& SHIVIK, J. (2001) Managing wolf conflict with livestock in the north-western United States. Carnivore Damage Prevention News, 3, 2-5.

Bauer, H. \& De Iongh, H.H. (2005) Lion (Panthera leo) home ranges and livestock conflicts in Waza National Park, Cameroon. African Journal of Ecology, 43, 208-214.

Bauer, H., Vanherle, N., Di Silvestre, I. \& De Iongh, H.H. (2008) Lion-prey relations in West and Central Africa. Mammalian Biology, 73, 70-73.

Binot, A., Castel, V. \& Caron, A. (2006) L'interface faune-bétail en Afrique subsaharienne. Sécheresse, 17, 349-361.

Bodendorfer, T., Hoppe-Dominik, B., Fischer, F. \& Linsenmair, K.E. (2006) Prey of the leopard (Panthera pardus) and the lion (Panthera leo) in the Comoé and Marahoué National Parks, Côte d'Ivoire, West Africa. Mammalia, 7o, 231-246.

Boer, W.F. De \& Baquete, D.S. (1998) Natural resource use, crop damage and attitudes of rural people in the vicinity of the Maputo Elephant Reserve, Mozambique. Environmental Conservation, 25, 208-218.

Boy, A. (1962) Lions des environs du Parc National du W Niger, Haute-Volta. Bois et Forêts des Tropiques, 86, 4-18. 
Boydston, E.E., Kapheim, K.M., Watts, H.E., Szykman, M. \& Holekamp, K.E. (2003) Altered behaviour in spotted hyenas associated with increased human activity. Animal Conservation, 6 , 207-219.

Brashares, J.S., Arcese, P. \& Sam, M.K. (2001) Human demography and reserve size predict wildlife extinction in West Africa. Proceedings of the Royal Society of London Series B, 268, 2473-2478.

BUTLER, J.R.A. (2000) The economic costs of wildlife predation on livestock in Gokwe communal land, Zimbabwe. African Journal of Ecology, 38, 23-30.

Caro, T.M. (1994) Cheetahs of the Serengeti Plains: Group Living in an Asocial Species. University of Chicago Press, Chicago, USA.

Conforti, V.A. \& de Azevedo, F.C.C. (2003) Local perceptions of jaguars (Panthera onca) and pumas (Puma concolor) in the Iguaçu National Park area, south Brazil. Biological Conservation, 111, 215-221.

Conover, M. (2002) Resolving Human-Wildlife Conflicts: The Science of Wildlife Damage Management. Lewis Publishers, Boca Raton, USA.

Cozza, K., Fico, R., B attistini, M.-L. \& Rogers, E. (1996) The damage-conservation interface illustrated by predation on domestic livestock in central Italy. Biological Conservation, 78 , 329-336.

Dahle, B., Sørensen, O.J., Wedul, H., Swenson, J.E. \& SANDEgren, F. (1998) The diet of brown bears in central Scandinavia: effect of access to free-ranging domestic sheep. Wildlife Biology, 3, 147-158.

Delvingt, W., Heymans, J.-C. \& Sinsin, B. (1989) Guide du Parc National de la Pendjari. CECA-CEE-CEEA, DFRN/MDR, Cotonou, Bénin.

Di Silvestre, I. (2002) Dénombrement des grands carnivores au niveau de la Réserve de Biosphère de la Pendjari. Unpublished Report to CEMAGREF/GTZ, Projet Pendjari, Cotonou, Benin.

DoAK, D.F. (1995) Source-sink models and the problem of habitat degradation: general models and applications to the Yellowstone grizzly. Conservation Biology, 9, 1370-1379.

EAst, R. (1984) Rainfall, soil nutrient status and biomass of large African savanna mammals. African Journal of Ecology, 22, 245-270.

Eltringham, S.K., Cooksey, I.A., Dixon, W.J.B., Raine, N.E., Sheldrick, C.J., MCWilliam, N.C. \& Packer, M.J. (1999) Large mammals of Mkomazi. In Mkomazi: The Ecology, Biodiversity and Conservation of a Tanzanian Savanna (eds M. Coe, N. McWilliam, G. Stone \& M. Packer.), pp. 485-504. Royal Geographical Society, London, UK.

Fritz, H. (1997) Low ungulate biomass in West African savannas: primary production or missing megaherbivores or large predator species. Ecography, 20, 417-421.

Garba, H.M. \& Di Silvestre, I. (2008) Conflicts between large carnivores and domestic livestock in the peripheral zone of the Regional Park 'W' in Niger. In Proceedings of an International Seminar on Management and Conservation of Large Carnivores in West and Central Africa (eds B. Croes, R. Buij, H.H. de Iongh \& H. Bauer), pp. 133-144. Leiden, The Netherlands.

Ginsberg, J.R. \& Macdonald, D.W. (1990) Foxes, Wolves, Jackals and Dogs: An Action Plan for the Conservation of Canids. IUCN, Gland, Switzerland.

Graham, K., Beckerman, A.P. \& Thirgood, S. (2005) Humanpredator-prey conflicts: ecological correlates, prey losses and patterns of management. Biological Conservation, 122, 159-171.
HANSKI, I. (2005) Landscape fragmentation, biodiversity loss and the societal response. EMBO Reports, 6, 388-392.

Hayward, M.W. (2006) Prey preferences of the spotted hyaena (Crocuta crocuta) and degree of dietary overlap with the lion (Panthera leo). Journal of Zoology, 270, 606-614.

Hofer, H. \& East, M.L. (1993) The commuting system of Serengeti spotted hyaenas: how a predator copes with migratory prey. I. Social organization. Animal Behaviour, 46, 547-557.

Holmern, T., Nyahongo, J. \& Røskaft, E. (2007) Livestock loss caused by predators outside the Serengeti National Park, Tanzania. Biological Conservation, 135, 518-526.

Hoogesteijn, R., Hoogesteijn, A. \& Mondolfi, E. (1993) Jaguar predation and conservation: cattle mortality caused by felines on three ranches in the Venezuelan Llanos. Symposium of the Zoological Society of London, 65, 391-407.

Hunter, J.A. (1952) Hunter. Harper and Brothers Publishers, New York, USA.

Hussain, S. (2003) The status of the snow leopard in Pakistan and its conflict with local farmers. Oryx, 37, 26-33.

JACKSON, R. \& WANGEHUK, R. (2001) Linking snow leopard conservation and people-wildlife conflict resolution: grassroots measures to protect the endangered snow leopard from herder retribution. Endangered Species Update, 18, 138-141.

Karani, I.W. (1994) An Assessment of Depredation by Lions and Other Predators in the Group Ranches Adjacent to Masai Mara National Reserve. MSc thesis, Moi University, Eldoret, Kenya.

Kays, R.W. \& Patterson, B.D. (2002) Mane variation in African lions and its social correlates. Canadian Journal of Zoology, 80, 471-478.

Kerbis Peterhans, J.C. \& Gnoske, T.P. (2002) The science of man-eating among lions Panthera leo with a reconstruction of the natural history of the man-eaters of Tsavo. Journal of East African Natural History, 90, 1-40.

Kolowski, J.M. \& Holekamp, K.E. (2006) Spatial, temporal, and physical characteristics of livestock depredations by large carnivores along a Kenyan reserve border. Biological Conservation, 128, 529-541.

KRUU K, H. (1972) The Spotted Hyena: A Study of Predation and Social Behaviour. The University of Chicago Press, Chicago, USA.

LAMARQUe, F. (2004) Les grands mammifères du complexe WAP. ECOPAS, Ouagadougou, Burkina Faso.

Liu, J., Linderman, M., OUYang, Z., An, L., YanG, J. \& Zhang, H. (2001) Ecological degradation in protected areas: the case of Woolong Nature Reserve for giant pandas. Science, 292, 98-101.

MARKer, L.L. (2002) Aspects of cheetah (Acinonyx jubatus) biology, ecology and conservation strategies on Namibian farmlands. $\mathrm{PhD}$ thesis, University of Oxford, Oxford, UK.

Marker-Kraus, L., Kraus, D., Barnett, D. \& Hurlbut, S. (1996) Cheetah Survival on Namibian Farmlands. Cheetah Conservation Fund, Windhoek, Namibia.

Mazzolli, M., Graipel, M.E. \& Dunstone, N. (2002) Mountain lion depredation in southern Brazil. Biological Conservation, 105, 43-51.

Meriggi, A. \& Lovari, S. (1996) A review of wolf predation in southern Europe: does the wolf prefer wild prey to livestock. Journal of Applied Ecology, 33, 1561-1571.

Michalski, F., Boulhosa, R.L.P., Faria, A. \& Peres, C.A. (2006) Human-wildlife conflicts in a fragmented Amazonian forest landscape: determinants of large felid depredation on livestock. Animal Conservation, 9, 179-188.

Michelle, D.G. \& Smirnov, E.N. (1999) People and tigers in the Russian Far East: searching for the 'co-existence receipe'. In 
Riding the Tiger: Tiger Conservation Efforts in Human-Dominated Landscapes (eds J. Seidensticker, S. Christie \& P. Jackson), pp. 273-295. Cambridge University Press, Cambridge, UK.

Mills, G. \& Hofer, H. (1998) Hyenas: Status Survey and Conservation Action Plan. IUCN, Gland, Switzerland.

Mishra, C. (1997) Livestock depredation by large carnivores in the Indian trans-Himalaya: conflict perceptions and conservation prospects. Environmental Conservation, 24, 338-343.

Mishra, C., Allen, P., McCarthy, T., Madhusudan, M.D., Bayarjargal, A. \& Prins, H.H.T. (2003) The role of incentive programs in conserving the snow leopard. Conservation Biology, $17,1512-1520$.

Mizutani, F. (1999) Impacts of leopards on a working ranch in Laikipia, Kenya. African Journal of Zoology, 37, 211-225.

Mladenoff, D.J., Haight, R.G., Sickley, T.A. \& Wydeven, A.P. (1997) Causes and implications of species restoration in altered ecosystems. BioScience, 47, 21-31.

Naughton-Treves, L., Grossberg, R. \& Treves, A. (2003) Paying for tolerance: rural citizens' attitudes toward wolf depredation and compensation. Conservation Biology, 17, 1500-1511.

Naughton-Treves, L., Treves, A., Chapman, C. \& Wrangham, R. (1998) Temporal patterns of crop-raiding by primates: linking food availability in croplands and adjacent forest. Journal of Applied Ecology, 35, 596-606.

Noss, R.F., Dinerstein, E., Gilbert, B., Gilpin, M., Miller, B.J., Terborgh, J. \& Trombulak, S. (1999) Core areas: where nature reigns. In Continental Conservation: Scientific Foundations of Regional Reserve Networks (eds M.E. Soulé \& J. Terborgh), pp. 99128. The Wildlands Project, Island Press, Washington, DC, USA.

Nowell, K. \& Jackson, P. (1996) Wild Cats: Status Survey and Conservation Action Plan. IUCN/Species Survival Commission Cat Specialist Group, Gland, Switzerland.

Ogada, M.O., Woodroffe, R., Oguge, N.O. \& Frank, L.G. (2003) Limiting depredation by African carnivores: the role of livestock husbandry. Conservation Biology, 17, 1521-1530.

Oli, M.K., Taylor, I.R. \& Rogers, M.T. (1994) Snow leopard (Panthera uncia) predation on livestock: an assessment of local perceptions in the Annapurna Conservation Area, Nepal. Biological Conservation, 68, 63-68.

Packer, C., Ikanda, D., Kissui, B. \& Kushnir, H. (2005) Lion attacks on humans in Tanzania. Nature, 436, 927-928.

Palmeira, F.B.L., Crawshaw, Jr, P.G., Haddad, C.M., Ferraz, K.M.P.M.B. \& VERDADE, L.M. (2008) Cattle depredation by puma (Puma concolor) and jaguar (Panthera onca) in centralwestern Brazil. Biological Conservation, 141, 118-125.

Patterson, B.D., Kasiki, S.M., Selempo, E. \& Kays, R.W. (2004) Livestock predation by lions (Panthera leo) and other carnivores on ranches neighboring Tsavo National Park, Kenya. Biological Conservation, 119, 507-516.

Polisar, J., Matix, I., Scognamillo, D., Farrell, L., Sunquist, M.E. \& EisenberG, J.F. (2003) Jaguars, pumas, their prey base, and cattle ranching: ecological interpretations of a management problem. Biological Conservation, 109, 297-310.

Rasmussen, G.S.A. (1999) Livestock predation by the painted hunting dog Lycaon pictus in a cattle ranching region of Zimbabwe: a case study. Biological Conservation, 88, 133-139.

Rigg, R., Findoo, S., Wechselberger, M., Gorman, M.L., Sillero-Zubiri, C. \& Macdonald, D.W. (2011) Mitigating carnivore-livestock conflict in Europe: lessons from Slovakia. Oryx, 45, 272-280.

Robel, R.J., Dayton, A.D., Henderson, R.R., Meduna, R.L. \& Spaeth, C.W. (1981) Relationships between husbandry methods and sheep losses to canine predators. Journal of Wildlife Management, 45, 894-911.

Rudnai, J. (1979) Ecology of lions in Nairobi National Park and the adjoining Kitengela Conservation Unit in Kenya. African Journal of Ecology, 17, 85-95.

Saberwal, V.K., Gibbs, J.P., Chellam, R. \& Johnsingh, A.J.T. (1994) Lion-human conflict in the Gir Forest, India. Conservation Biology, 8, 501-507.

Sogbohossou, E.A. (2004) Etude des conflits entre les grands carnivores et les populations riveraines de la Réserve de Biosphère de la Pendjari, Nord Bénin. Unpublished Report to MAB UNESCO/Laboratory of Applied Ecology, Calavi, Benin.

Sog воно ssou, E.A. (2009) Dénombrement des lions dans la Réserve de Biosphère de la Pendjari. Rapport Technique. Unpublished Report to DPNP/ProCGRN, Cotonou, Benin.

Stahl, P., Vandel, J.M., Herrenschmidt, V. \& Migot, P. (2001) Predation on livestock by an expanding reintroduced lynx population: long-term trend and spatial variability. Journal of Applied Ecology, 38, 674-687.

STANDER, P.E. (1990) A suggested management strategy for stockraiding lions in Namibia. South African Journal of Wildlife Resources, 20, 37-43.

Thouless, C.R. \& SAKWA, J. (1995) Shocking elephants: fences and crop raiders in Laikipia District, Kenya. Biological Conservation, 72, 99-107.

Treves, A. \& Karanth, K.U. (2003) Human-carnivore conflict and perspectives on carnivore management worldwide. Conservation Biology, 17, 1491-1499.

Van Bommel, L., Bij de Vaate, M.D., Boer, W.F. De \& Iongh, H.H. DE (2007) Factors affecting livestock predation by lions in Cameroon. African Journal of Ecology, 45, 490-498.

W A gner, F.H. (1988) Predator Control and the Sheep Industry: The Role of Science in Policy Formation. Regina Books, Claremont, USA.

WANG, S.W. \& MACDONALD, D.W. (2006) Livestock predation by carnivores in Jigme Singye Wangchuk National Park, Bhutan. Biological Conservation, 129, 558-565.

Woodroffe, R. (2000) Predators and people: using human densities to interpret declines of large carnivores. Animal Conservation, 3 , $165-173$.

Woodroffe, R. \& Ginsberg, J.R. (1998) Edge effects and the extinction of populations inside protected areas. Science, 280 , 2126-2128.

Zimmermann, A., Walpole, M.J. \& Leader-Williams, N. (2005) Cattle ranchers' attitudes to conflicts with jaguar Panthera onca in the Pantanal of Brazil. Oryx, 39, 406-412.

\section{Biographical sketches}

ET T TÉPÉ A. works to conserve carnivores in West and Central Africa and is interested in lion ecology and behaviour and human-lion conflict in West Africa. HANS H. DE IONGH is involved in research on the conservation of large carnivores in West and Central Africa. BRICE SINSIN has led several programmes on natural resources and conflicts related to wildlife conservation in West African protected areas for more than 20 years. GeERT R. DE SNOO works in conservation biology with a focus on the impact of human activities on biodiversity. PAUL J. FUnSTON has studied the conservation of large carnivores and behavioural ecology in Africa for the last 20 years. 